\title{
Clay Minerals as Climate Change Indicators-A Case Study
}

\author{
A. R. Chaudhri, Mahavir Singh \\ Department of Geology, Kurukshetra University, Kurukshetra, India \\ Email: archaudhri@gmail.com,07mahavir@gmail.com
}

Received September 29, 2012; revised October 30, 2012; accepted November 10, 2012

\begin{abstract}
The clay mineralogy of the Late Pliocene-Early Pleistocene Pinjor Formation of the type area, northwestern Himalaya, India has been investigated to understand the paleoclimatic conditions and paleotectonic regime prevailing in the frontal Himalayan terrain during $2.5 \mathrm{Ma}$ to $1.7 \mathrm{Ma}$. The clay minerals were investigated by X-ray diffraction analysis and scanning electron microscope studies. Study of the oriented aggregates of 47 representative clay samples of the Pinjor Formation of the type area reveals that illite is the most dominant mineral followed by chlorite, kaolinite, vermiculite and mixed layer clay minerals. The distribution of the clay minerals in the three lithostratigraphic units of the Formation, namely the Kona Clay Member, the Tanda Bhagwanpur Wacke Member and the Chauki Nadah Pebbly Bed Member which are well exposed along the Berwala-Mandhna section, the Kona-Karaundanwala section and the Ghaggar River-Chauki Nadah section, is nearly uniform suggesting thereby the prevalence of similar sedimentation environments in the Himalayan foreland basin. The presence of illite and kaolinite suggests their derivation from crystalline rocks containing felspar and mica as also from pre-existing soils and sedimentary rocks. Further, the paleoclimatic conditions were moderate. Presence of chlorite suggests the weathering of intermediate and basic crystalline rocks and low grade metamorphic rocks in the positive areas. The presence of kaolinite in the Pinjor Formation is mainly attributed to the weathering and subsequent leaching of the mineral from granitic and basic rocks in the hinterland. Vermiculite has been mainly formed by weathering and transformation of biotite. Warm and humid climatic conditions prevailed for a major part during the deposition of the detritus which favored weathering and transformation of minerals. During the terminal phase of sedimentation there was renewed tectonic activity which had a significant impact on climate as precipitation and mechanical weathering rates increased substantially. Post $1.7 \mathrm{Ma}$ there was a marked shift in temperature patterns and subsequent cooling of the landmass, which resulted in a decreased vegetation cover and a subsequent decrease in animal population thriving on it.
\end{abstract}

Keywords: Clay Minerals; Climate; Pinjor; Siwalik; Himalaya; India

\section{Introduction}

Clay mineral assemblage of the Late Pliocene-Early Pleistocene Pinjor Formation of the type area in northwestern Himalaya is of significant importance in understanding the paleoclimatic and paleotectonic conditions prevailing in the positive and negative areas and their interrelationship; types of source rocks, modes of sediment transport, sedimentation environments and post-depositional changes experienced by the sediments.

The Himalayan orogenic belt is topographically divided into three major sub divisions, namely the southernmost frontal Himalaya comprising the low lying Siwalik Hills, the middle Lesser Himalaya and the northern Great Himalayan belt. The Siwalik Group of northwestern Himalaya in India is exposed in a linear fashion along the Himalayan foothills for a distance of about $2400 \mathrm{~km}$. from near Jammu in the West to near Tripura in the East.
It represents a huge thickness of sediments ranging from $3300 \mathrm{~m}$ to $6300 \mathrm{~m}$ [1] which were deposited in a foredeep. The Late Pliocene-Early Pleistocene Pinjor Formation $(1.7 \mathrm{Ma}-2.5 \mathrm{Ma})$ of the Upper Siwalik Subgroup is very well exposed in the type area Pinjor and surrounding regions (Figure 1). The Formation attains a thickness of $703 \mathrm{~m}$ to $1800 \mathrm{~m}$. It overlies the Tatrot Formation (2.5 $\mathrm{Ma}-5.6 \mathrm{Ma})$ and is underlain by the Boulder Conglomerate Formation $(0.7 \mathrm{Ma}-1.7 \mathrm{Ma})$. The Pinjor Formation has a conformable gradational contact with underlying and overlying formations. Lithologically, the Formation consists of poorly to moderately indurated light grey to pale brown, medium to coarse grained, pebbly sandstones and pale brown to chocolate brown sandy clays. Reference [1] observed that the Siwalik Group of the western Himalayan is a product of two coarsening up mega cycles. The first mega cycle is represented by the Lower Siwalik/Nahan. Formation which is characterized 


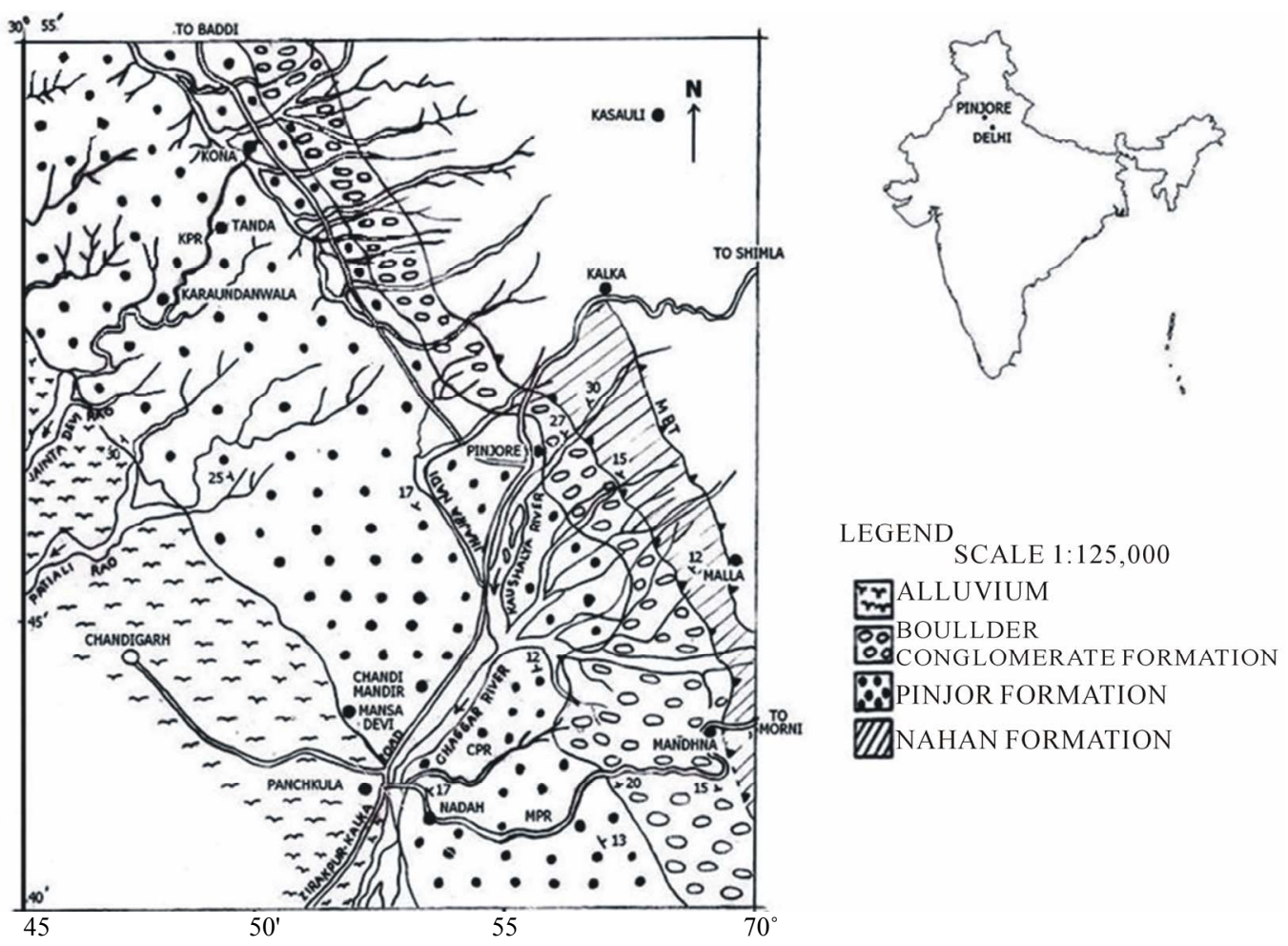

Figure 1. Geological map of the Pinjor Formation in the type area Pinjor and surrounding regions.

by a slow pace of erosion and sedimentation and stable paleotectonic conditions. The second mega cycle comprising the Middle and the Upper Siwalik formations is marked by coarsening of the sediments which eventually indicates a fast rate of degradation processes.

Significant contributions have been made by a number of workers during the past three decades on various aspects of clay minerals. Some of the more important contributions during the past decade have been made by [2-16].

\section{Analytical Techniques}

Being extremely small in size, clay minerals require special techniques for their investigation. These techniques include X-ray diffraction, infrared spectroscopy, differential thermal; thermo-gravimetric; chemical; scanning electron microscope, neutron scattering, electron spin resonance, neutron magnetic resonance, mossbauer spectroscopy and ultraviolet and visible light spectroscopy techniques. X-ray diffraction technique has been utilized for analyzing the clays of the Pinjor Formation mainly because of availability of instrument and reliability of the technique. Forty seven representative samples from each of the measured section and random samples of the Pinjor Formation were analyzed for clay mineral studies. The area of investigation spreads over 504 sq. $\mathrm{km}$. in the frontal Himalayan terrain. Samples showing variation in grain size, colour, petrography and modal percentage were selected for this analysis.

The samples were first crushed to -250 mesh ASTM sieve size. About $100 \mathrm{gm}$ of the sample powder was taken from each of the sample and the same was suspended in distilled water kept in $1000 \mathrm{ml}$ measuring jar for about 24 hours and stirred with perforated stirrer and then allowed to settle down. The stirring was done after every 6 - 8 hours. After that the clear water was decanted off from the jar and fresh distilled water was added. The process was repeated till the suspension of clay particles appeared in the standing water column. $100 \mathrm{ml}$ of suspended clays were separated out from a depth of $5 \mathrm{~cm}$ from the top of the standing water column with the help of pipette. The suspension so collected was put on glass slides and allowed to dry at the room temperature to obtain slides of oriented aggregates of clay minerals. The incident X-ray beam from the X-ray machine can be directed down the $\mathrm{Z}$ axis of the flat lying plate-shaped phyllosilicate minerals in the oriented aggregate slides thus facilitating the recording of diagnostic basal diffractions. The $\mathrm{Z}$ axis depicts the intensity of d-spacing indicative of different clay minerals during glycolation and heating [17].

The prepared samples were run on the X-ray machine operated at $35 \mathrm{kV}$ and $20 \mathrm{~mA}$ using nickel filter and $\mathrm{Cu}-\mathrm{K} \alpha$ radiations of wavelength $1.5418 \AA$. The scanning speed was maintained at $2^{\circ}$ per minute. The results were printed on electronically controlled recorder in the $2 \theta$ 
range $2^{\circ}-40^{\circ}$. The air dried samples were then treated with ethylene glycol vapours for 24 hours. The same process was repeated for obtaining the diffractograms of the glycolated samples. The diffractograms of the heated samples were obtained after heating the samples for about 5 hours at $500^{\circ} \mathrm{C}$ in an electric furnace. The diffractograms of the representative air dried, glycolated and heated samples of the analysed sediments are shown in the Figures 2-4. The values for the different peaks were indicated with reference to $2 \theta$ angle and subsequently converted into molecular plane repeat distances (d-spacing) in Angstrom ( $\AA$ ) with the help of conversion tables provided by $[18,19]$. The conversion is based on the Bragg's equation as expressed below:

$$
n \lambda=2 \mathrm{~d} \sin \theta
$$

where $\theta$ is the diffraction angle, $\mathrm{d}$ is molecular repeat distance for any multiple " $n$ " of any X-ray wavelength $\lambda$.

The SEM analysis of a few selected samples was carried out on JEOL, JSM 6100 scanning microscope. The samples were sputter coated and scanned for identification of the different clay minerals present therein.

\section{Clay Mineral Assemblage}

The different clay minerals which were identified in the Pinjor Formation of the type area and adjoining regions with the help of tables provided by [19-22] include illite,

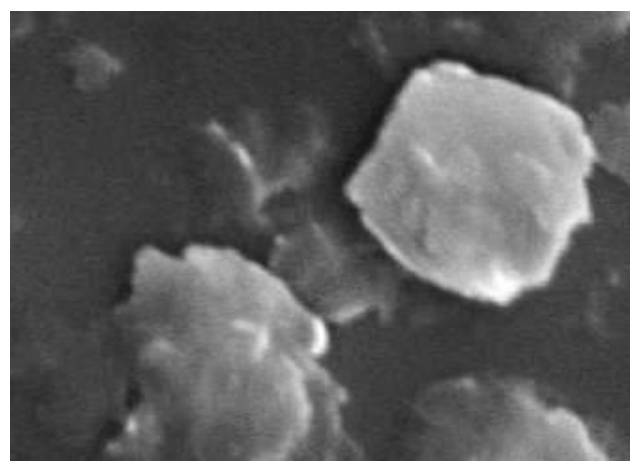

Figure 2. SEM photomicrographs of illite.

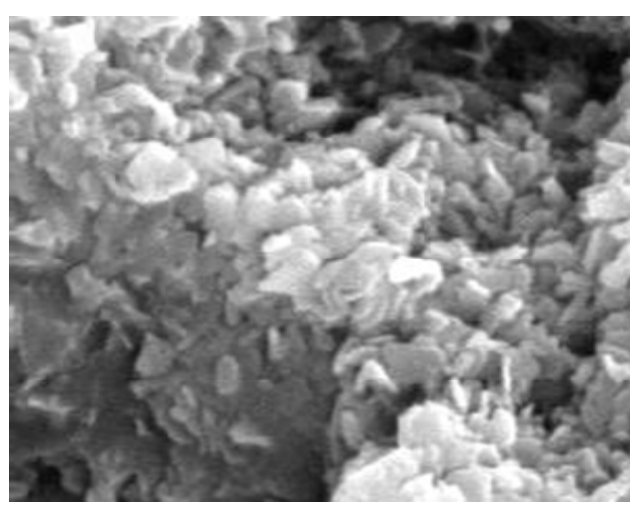

Figure 3. SEM photomicrographs of kaolinite. chlorite, kaolinite, vermiculite and mixed layer clay minerals (Figures 4-6).

\subsection{Illite}

Illite $\left(\mathrm{K}_{1-1.5} \mathrm{Al}_{4}\left[\mathrm{Si}_{7-6.5} \mathrm{Al}_{1-1.5} \mathrm{O}_{20}\right](\mathrm{OH})_{8}\right)$ is the most dominant clay mineral. It forms about $40 \%$ of the total clay mineral assemblage. The basal spacing at $10 \AA$ shows the most dominant peak corresponding to basal reflection along (001) plane. Reflection at $4.98 \AA$ corresponding to (002) are weaker than those at $3.32 \AA$. Organic liquids do not have any effect on the mineral as it contains little or no inter-layer water. Therefore it does not show any change on glycolation and remains unaffected on heating up to $500^{\circ} \mathrm{C}$.

The SEM photomicrographs of dioctahedral/trioctahedral illite (Figure 2) reveal a poor to moderately developed crystalline structure. In some samples illite shows poorly developed crystalline structure.

\subsection{Chlorite}

Chlorite $\left((\mathrm{Mg}, \mathrm{Al}, \mathrm{Fe})_{12}\left[(\mathrm{Si}, \mathrm{Al})_{8} \mathrm{O}_{20}\right](\mathrm{OH})_{16}\right)$ comprises about $31 \%$ of the total clay mineral assemblage. The mineral shows strong reflection along the (003) plane. The 4.75 $\AA$ peak is stronger than the $3.56 \AA$ peak. The reflection along the (001) plane are extremely poor. The peak of the mineral, which consists of an octahedral layer sandwiched between tetrahedral layers and a single octahedral layer repeating on $\mathrm{C}$, does not show any change after ethylene glycol treatment and heating as it contains little or no interlayer water.

\subsection{Kaolinite}

Kaolinite $\left(\mathrm{Al}_{2} \mathrm{SiO}_{2} \mathrm{O}_{5}(\mathrm{OH})_{4}\right)$ comprises about $15 \%$ of the total clay mineral assemblage.

The reflection at (001) plane corresponding to $7.16 \AA$ is more intense than those from (020) and (110) planes. The peak at $4.36 \AA$ is stronger than the peak at $4.46 \AA$. The peaks of the dioctahedral kaolinite remain unaffected upon ethylene glycol treatment but get destroyed on heating above $450^{\circ} \mathrm{C}$. Heat treatment helps in distinguishing kaolinite from chlorite which too has the basal reflection at $7.12 \AA$. Crystalline structure of kaolinite is present in a few SEM photomicrographs (Figure 3).

\subsection{Vermiculite}

Vermiculite $\left(\mathrm{Mg}_{3}\left(\mathrm{Si}_{3} \mathrm{Al}\right) \mathrm{O}_{10}(\mathrm{OH})_{2} \mathrm{Mg}_{0.5}\left(\mathrm{H}_{2} \mathrm{O}_{4}\right)_{4}\right)$ forms about $10 \%$ of the total clay mineral assemblage. The peak at $14.4 \AA$ corresponding to (002) plane is stronger than the peak corresponding to $2.39^{\circ}$. The reflection along the $(021,111)$ planes and along $(060,330,332)$ planes are not distinct. The $14.4 \AA$ peak of the trioctahedral vermiculite, containing strongly linked water molecule to 

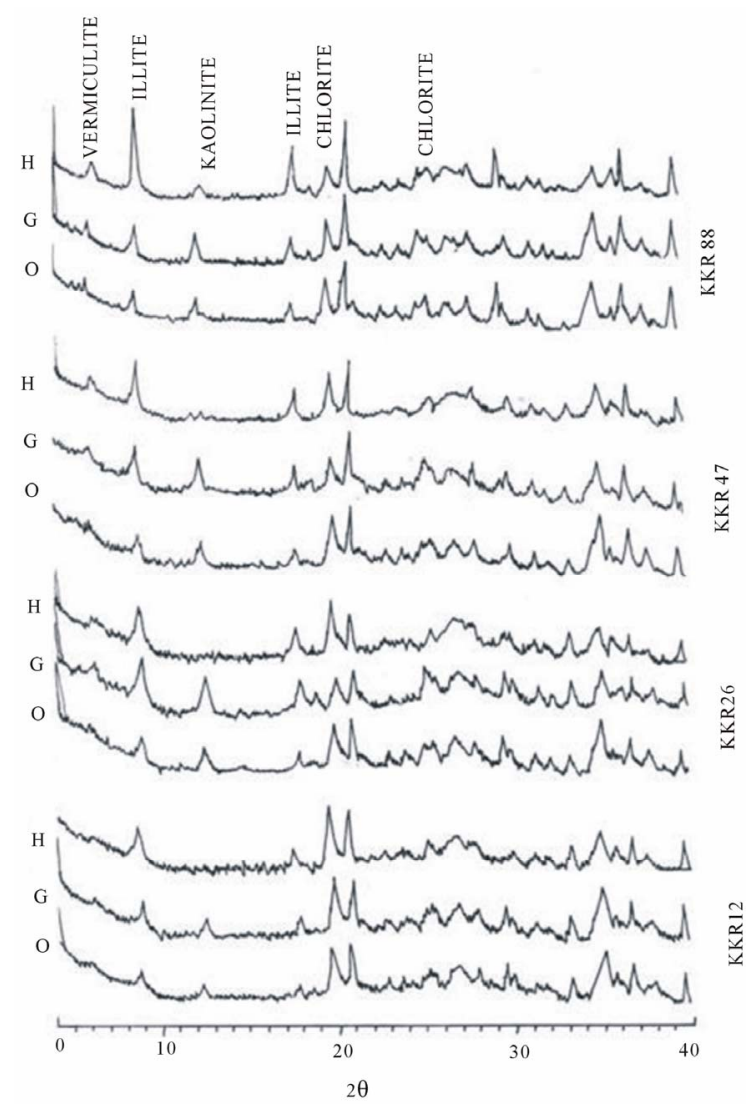

O-ORIENTED G-GLYCOLATED H-HEATED

Figure 4. X-ray diffractograms of clay minerals of selected samples of Pinjor Formation of the kona-karaundanwala sec- tion.

the layer structure, expands to $15 \AA$ - $16 \AA$ on glycolation but collapses to $10 \AA$ on heating up to $500^{\circ} \mathrm{C}$.

\subsection{Mixed-Layer Clay Minerals}

Mixed-layer clay minerals form about $4 \%$ of the total clay mineral assemblage. These are formed as a consequence of regular, irregular or segregation of alternating packets which frequently occur in the sediments of the Pinjor Formation. Irregular mixed-layers are generally more conspicuous than regular mixed-layers and are characterized by a series of non-linear reflections which result due to interference of very close diffracted rays.

\section{Interpretation of Results}

Clay minerals are the products of weathering and soil formation processes. The variation in the clay mineral assemblage is indicative of paleoclimatic changes, the cyclicity of tectonic activity and diagenetic modifications experienced by the sedimentary horizon.

Illite in Pinjor Formation is primarily a product of detrital origin being derived from weathered crystalline rocks containing felspars and micas in the source areas
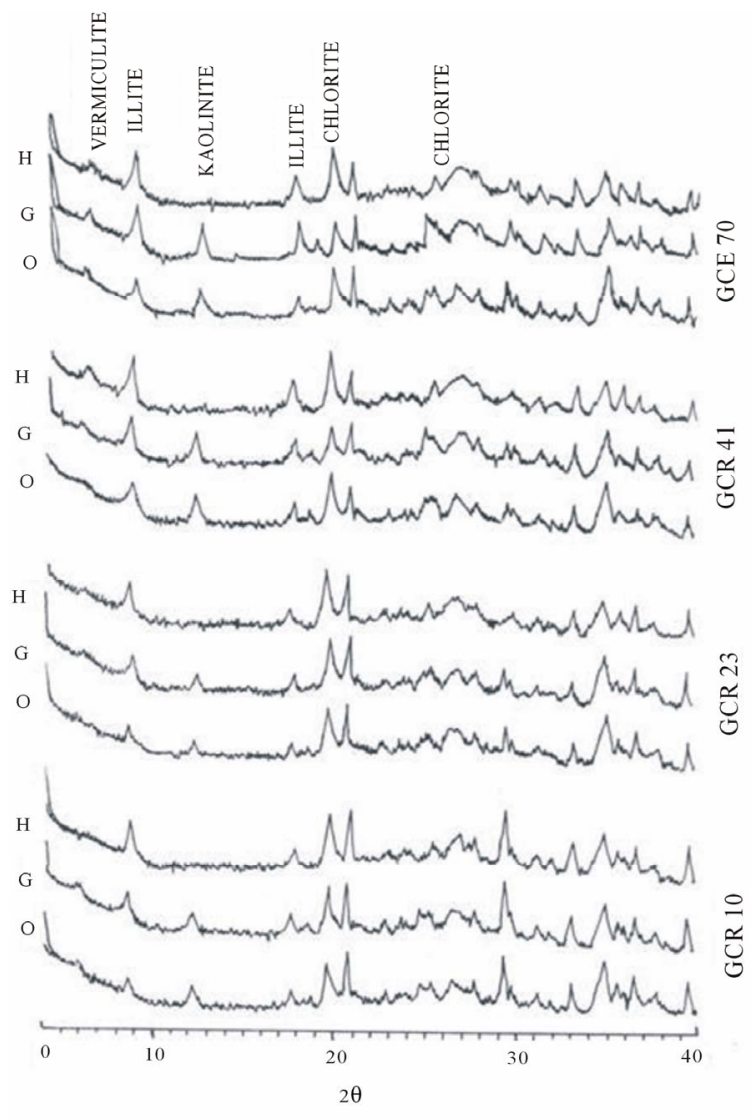

O-ORIENTED G-GLyCOLATED H-HEATED

Figure 5. X-ray diffractograms of clay minerals of selected samples of Pinjor Formation of ghaggar river-chauki nadah section.

and from soils and pre-existing sedimentary rocks in the drainage basin of fluvial channel(s) that deposited the Pinjor sediments.

Chlorite is formed by weathering of intermediate and basic crystalline rocks and low grade metamorphic rocks. Millot [23-25] observed that chlorite is stable during weathering and diagenesis. Reference [26] recorded that the mineral forms by aggradation of less organized sheet minerals, degradation of pre-existing ferromagnesian minerals and by crystallization of dilute solutions containing chlorite components.

Chlorite in the Pinjor Formation has been derived from weathering of crystalline and metamorphic rocks exposed in the source areas.

Kaolinite is formed by weathering of granitic and basic rocks [27]. The presence of kaolinite in the Pinjor Formation is mainly attributed to the weathering and subsequent leaching of the mineral from these rocks in the source regions. Silicon and aluminum are the major chemical elements needed for kaolinite formation and these are derived by leaching of potassium felspars and micas present in the pre-existing rocks. The presence of kaolinite in the Pinjor Formation indicates the prevalence 


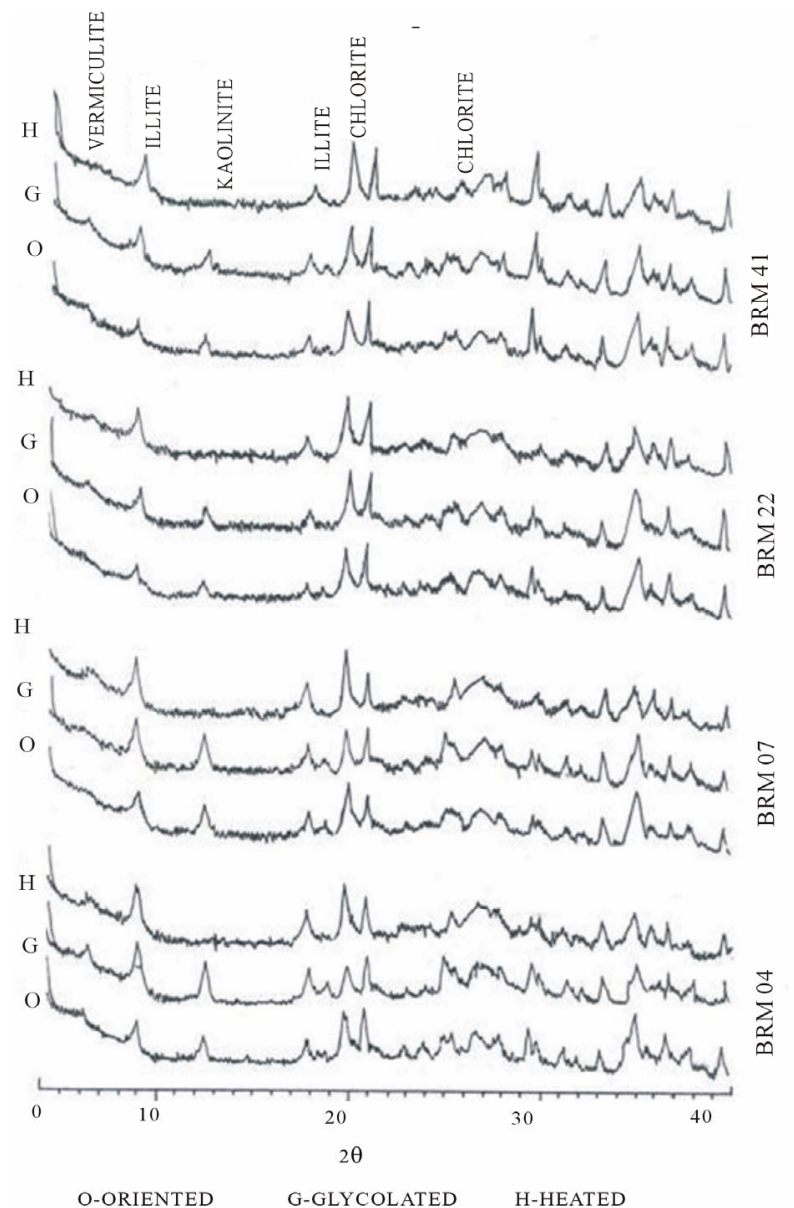

Figure 6. X-ray diffractograms of clay minerals of selected samples of Pinjor Formation of berwala-mandhna section.

of acidic conditions and presence of relict organic matter in the source areas and near neutral $\mathrm{pH}$ conditions in the basin of deposition.

Vermiculite forms as a result of selective fixation of potassium during diagenesis and as a consequence of alteration of fluorite and illite [28]. The mineral appears to be closely related to biotite and has been formed by weathering and transformation of iron bearing mica [29, 30]. Biotite is the most abundant heavy mineral in the rocks of the Pinjor Formation [31]. Loss of octahedral cations from biotite during weathering in an acidic environment results in selective replacement by $\mathrm{Al}$ and formation of vermiculite [32]. An aggressive weathering regime following high precipitation and chemical weathering of felspar and other intermediate weathering products has resulted in its development in the Pinjor Formation.

Mixed layer clay minerals are present in the all the samples of the Pinjor Formation. In nature, clay minerals usually occur intermixed with each other. Environments rich in $\mathrm{Na}^{+}$or $\mathrm{K}^{+}$ions help in the formation of mica and hydrous aluminosilicate mixed layers.

\section{Conclusions}

The Himalayan foreland basin has formed due to flexure of the Indian plate caused by the high mass of the evolving Himalayan mountain belt. Thrust tectonics, isostatic dynamics and load of overlain sediment have played a significant role in influencing the basin dynamics. The Siwalik sediments were deposited in a fore deep and represent the detrital products of the rather rapidly evolving Himalaya. The Himalayan tectonic activity reached its acme during the Quaternary period. During the period of deposition (Mid Miocene to Early Pleistocene) of the Siwalik sediments, the tectonic activity manifested itself in the formation of numerous fold and thrust structures [33], which intermittently increased the local relief triggering heightened erosion of the pre-existing rocks located adjacent to fore deep. The growth of the Himalaya also contributed significantly in altering the atmospheric circulation pattern and consequent climatic readjustments. The Indian Summer Monsoon (ISM) is perhaps the single most significant factor influencing the sediment supply of the foredeep sediments. Tectonic control of climate is best documented in the development of high relief intercontinental topographic barriers like the Himalayan mountain belt [34]. The rise of the Himalaya had a significant impact on the surface albedo and the atmospheric pressure regime which augmented the monsoon precipitation in the Himalayan terrain. Reference $[35,36]$ suggested that the weathering processes acting in young orogenic belt consume carbon dioxide and drive global cooling. Deep sea sediment studies carried out in the Arabian Sea suggest that the ISM had established itself as a consequence of the Himalayan Mountain rise around $10 \mathrm{Ma}$ and the monsoon intensity strengthened itself from about $8 \mathrm{Ma}[37,38]$. Evidence from deep sea drilling in Bengal fan suggested an accelerated uplift of the Higher Himalaya around $10 \mathrm{Ma}$ and subsequently after 0.9 Ma [39,40]. Studies from the Indus delta in the Arabian Sea carried out by [41] suggest the intensification of the Indian summer monsoon after $14 \mathrm{ka}$.

Sediment supply in mountain regions is a complex interplay of tectonically related rock uplift and degradation processes influenced by precipitation. Some researchers favour precipitation as the primary controlling factor for sediment supply $[42,43]$ while others favour tectonic uplift [44]. Reference [41] linked the volume and exhumation of the western Himalayan to the intensity of the summer monsoon.

In northwestern Himalaya rapid uplift of the Siwalik frontal range during Early Pleistocene to middle Pleistocene has been reported by [45]. Reference [34] suggested that coeval uplift and consequent degradation of the frontal Lesser Himalaya since $1 \mathrm{Ma}$ in Nepal had a perceptible influence on the composition of clay minerals observed in the deep sea Bengal Fan sediments. The top 
most horizon of upper Siwalik Subgroup, the Boulder Conglomerate Formation, which overlies the Pinjor Formation is indicative of fresh phase of accelerated uplift of the frontal range. This uplift, on the basis of dwindling fossil assemblage, also marks a distinct change in climate from temperate to a more cool regime. Reference [46,47] concluded that Siwalik sediments were deposited in shallow fast sinking fresh water basin. He observed the imprints of Pleistocene glaciations on the megaclasts of the Upper Siwalik Boulder Conglomerate. He suggested that Middle Pleistocene orogenic movement were responsible for the present day relief of Cenozoic sediments.

The characteristic of clay minerals in terms of the mineral type and abundance is dependent upon three major factors viz, detrital inheritance, transformation and neoformation. Clay minerals serve as reliable indicator of provenance and environments of sedimentation. Clay minerals are susceptible to alteration during transportation and accumulation in varying environments. The mineral illite is formed by weathering of felspathic and micaceous rock [48] which is stable in moderate climatic conditions and remains unaltered during transportation by fluvial agencies over a short distance of transport [49]. A temperate environment and moderate weathering conditions have been recorded for the formation of Illite by [50]. Reference [51] suggested that illite is formed as a consequence of absorption of potassium from sea water by montmorrillonite. Digenetic origin of illite has been suggested by $[6,7,12,52-54]$. The clay mineral assemblage recorded from the Lower, Middle and Upper Siwalik subgroups in the northwestern Himalaya show variation in the mineralogy and abundance of different clay minerals [1]. In Lower Siwalik sediments, illite is the most dominant clay mineral followed by kaolinite, mixed layers and vermiculite. Chlorite and montmorillonite are nearly absent. In Middle Siwalik sediments a similar scenario persists with the difference that the abundance of vermiculite is severely reduced and montmorillonite is present in a few samples. In Upper Siwalik Pinjor Formation illite is the most dominant mineral followed by chlorite, kaolinite, vermiculite and mixed layer clay minerals. This variation in abundance of clay minerals reflects variation in source rocks, change in precipitation regime consequent to tectonism, variation in weathering pattern and distance of transport of the detritus and post depositional alterations/neoformation of the clay minerals. Siwalik sediments record reveals a slow pace of sedimentation for the Lower and Middle subgroups and a rather fast pace of sedimentation for the upper Siwalik subgroup. Degradation of the Himalayan hinterland during the deposition of this thick foreland stratigraphic unit resulted in successive unroofing of the evolving Himalaya and exposure of new hitherto buried lithologies to denudation processes. A variation in rates of tectonic uplift at local and regional scales as also uplift along thrusts and faults caused a change in precipitation levels and erosional patterns. The clay minerals/sediments of the Lower and the Middle Siwalik subgroups which were buried under the load of the overlying sediments underwent transformation/neoformation.

The clay minerals of the Pinjor Formation are detrital in nature and have been derived from weathered crystalline rocks containing felspars and micas in the source areas and from soils and pre-existing sedimentary rocks in the drainage basin of fluvial channel(s) that deposited the Pinjor sediments [55]. Warm and humid climatic conditions prevailed for a major part during the deposition of the detritus which favored weathering and transformation of minerals. The recurrent tectonic activity had a perceptible influence on precipitation and chemical/physical weathering regime. During the terminal phase of sedimentation of the Pinjor Formation there was renewed tectonic activity which disturbed the sedimentation dynamics. Pebble and boulder sized fragments dominated the detritus that was transported by mud laden streams and deposited in the foredeep after a short transport. The tectonic activity at this stage had a significant impact on climate as precipitation and mechanical weathering rates increased substantially. This period marked a shift in temperature patterns and subsequent cooling of the landmass, which resulted in a decreased vegetation cover and a subsequent decrease in animal population thriving on it during the deposition of the detritus constituting the overlying Boulder Conglomerate Formation.

The clay mineral assemblage of the Pinjor Formation reflects the climatic evolution from a warm and humid spell during the major part of the deposition of the detritus to a cool and dry spell during the terminal phases of its deposition. Although Reference [56-58] and others have conducted some paleoclimatic studies on Indian monsoons and their evolution, detailed measurements of oxygen and hydrogen isotopes in authigenic clays of the Pinjor Formation could be made use of to estimate the precipitation patterns prevailing within the Himalayan foreland basin during the time span of the deposition of Pinjor Formation. The temperature change during the deposition of the Pinjor sediments could also be attempted through clumped isotope temperature analysis or $\delta \mathrm{D}$ analysis of individual leaf wax biomarkers [59].

Globally, past Miocene there has been a general cooling trend as global ice volume has increased, which has resulted in the weakening of the Indian summer monsoon precipitation regime since $2.7 \mathrm{Ma}$.

\section{Acknowledgements}

The authors wish to record their sincere gratitude to Prof. Dr. R. S. Chaudhri for his constant support and guidance. The work was carried out at Department of Geology, 
Kurukshetra University, Kurukshetra.

\section{REFERENCES}

[1] R. S. Chaudhri, "Fifty Years of Research on Sustainable Resource Management in Shivaliks," In: S. P. Mittal, R. K. Aggarwal and J. S. Samra, Eds., Geology of the Siwalik Group of Western and Central Himalaya, Central Soil and Water Conservation Research and Training Institute, Research Centre, Chandigarh, 2000, pp. 3-18.

[2] B. Parkash, R. P. Sharma and A. K. Roy, "The Siwalik Group Molasse, Sediments Shed by Collision of Continental Plates," Sedimentary Geology, Vol. 251, No. 2, 1980, pp. 127-159. doi:10.1016/0037-0738(80)90058-5

[3] J. J. Fripiat, "Advanced Techniques for Clay Mineral Analysis," Elsevier Scientific Publication Company, Amsterdam, 1982, pp. 235.

[4] R. S. Chaudhri and G. T. S. Gill, "Clay Mineralogy of the Siwalik Group of the Simla Hills, Northwestern Himalaya," Journal of Geological Society of India, Vol. 24, 1983, pp. 159-165.

[5] V. Raiverman, S. V. Kunte and A. Mukherjea, "Basin Geometry, Cenozoic Sedimentation and Hydrocarbon Prospects in Northwestern Himalaya and Indo-Gangetic Plains," Petroleum Asian Journal, Vol. 6, 1983, pp. 6792.

[6] R. S. Chaudhri and N. Ramanujam, "Clay Mineralogy of the Tal Formation of the Mussoorie Hills, Kumaon Himalaya," Publication Centre Advance Study of Geology, Panjab University, Chandigarh, 1985.

[7] R. S. Chaudhri and H. S. Grewal, "Clay Mineral Assemblage of the Jaunsar Group of Northwestern Himalaya," Indian Journal of Earth Sciences, Vol. 15, 1988, pp. 228233.

[8] H. Chamley, "Clay Sedimentology," Springer-Verlag, Berlin, 1989.

[9] D. W. Burbank, L. A. Derry and C. France-Lanord, "Reduced Himalayan Sediments Production 8 Myr Ago despite an Intensified Monsoon," Nature, Vol. 364, No. 6432, 1993, pp. 48-50. doi:10.1038/364048a0

[10] T. N. Bagati and R. Kumar, "Clay Mineralogy of Middle Siwalik Sequence in Mohand Area, Dehradun: Implication for Climate and Source Area," In: R. Kumar, S. K. Ghosh and N. R. Phadtare, Eds., Siwalik Foreland Basin of Himalaya, Himalayan Geology, Special Publication, 1994, pp. 219-228.

[11] A. Delgado and E. Reyes, "Oxygen and Hydrogen Isotope Composition in Clay Minerals: A Potential SingleMineral Geothermometer," Geochimica et Cosmochimica Acta, Vol. 60, No. 21, 1996, pp. 4285-4289. doi:10.1016/S0016-7037(96)00260-8

[12] A. R. Chaudhri, "Clay Mineralogy of the Nagthat Formation of the Chakrata Hills, Northwestern Himalaya," Journal of Indian Association of Sedimentologist, Vol. 12, No. 2, 1997, pp. 261-266.

[13] V. Raiverman and N. Suresh, "Clay Minerals Distribution in the Cenozoic Sequence of the Western Himalayan
Foothills," Journal of Indian Association of Sedimentologist, Vol. 16, No. 1, 1997, pp. 63-75.

[14] L. A. Stern, C. P. Chamberlain, R. C. Reynolds and G. D. Johnson, "Oxygen Isotope Evidence of Climate Change from Pedogenic Clay Minerals in the Himalayan Molasse," Geochimica et Cosmochimica Acta, Vol. 61, No. 4, 1997, pp. 731-744. doi:10.1016/S0016-7037(96)00367-5

[15] N. Suresh, S. K. Ghosh, R. Kumar and S. J. Sangode, "Clay Mineral Distribution Pattern in Late Neogene Fluvial Sediments of Subathu Sub-Basin, Central Sector of Himalayan Foreland Basin: Implication for Provenance and Climatic Condition," Sedimentary Geology, Vol. 163, No. 3-4, 2004, pp. 265-278. doi:10.1016/j.sedgeo.2003.07.006

[16] S. Ahmed and S. I. Hasnain, "Textural, Mineralogical and Geochemical Characteristics of Sediment and Soil at High Altitude Catchment in the Garhwal Himalaya," Geological Survey of India, Vol. 69, 2007, pp. 291-294.

[17] L. J. Poppe, V. F. Paskevich, J. C. Hathaway and D. S. Blackwood, "A Laboratory Manual for X-Ray Powder Diffraction," USGS Open File Report, 2002, pp. 1-41.

[18] G. Switzer, J. M. Axelrod, M. L. Lindbergh and E. S. Larsen, "Tables of d-Spacings for Angle $2 \theta \operatorname{Cuk} \alpha, \operatorname{Cuk} \alpha 1$, Cuk $\alpha 2$, Fek $\alpha$, Fek $\alpha 1$ Fek $\alpha 2$," United States Geological Survey Circulation, Reston, 1948.

[19] G. M. Griffin, "Interpretation of X-Ray Diffraction Data," In: R. E. Carver, Ed., Procedures in Sedimentary Petrology, Wiley Interscience, New York, 1971, pp. 541-569.

[20] G. Brown, "The X-Ray Identification and Crystal Structure of Clay Minerals-A Symposium," Mineralogical Society of London, London, 1961.

[21] G. W. Brindley and G. Brown, "Crystal Structures of Clay Minerals and Their X-Ray Identification," Mineralogical Society of London, London, 1980.

[22] S. W. Bailey, G. W. Brindley, D. S. Fanning, H. Kodama and R. T. Martin, "Report of the Clay Mineral Society, Nomenclature Committee for 1982 and 1983," Clays and Clay Minerals, Vol. 32, No. 3, 1984, pp. 239-240. doi:10.1346/CCMN.1984.0320316

[23] G. Millot, "Geology of Clays," Springer-Verlag, New York, 1970.

[24] R. M. Quigley and R. T. Martin "Chloritised Weathering Products of the New England Glacial Till," Clays and Clay Minerals, Vol. 10, 1963, pp. 107-116. doi:10.1346/CCMN.1961.0100110

[25] J. J. Griffin and E. D. Goldberg, "Clay Mineral Distribution in the Pacific Ocean," In: M. N. Hill, Ed., The Sea, Interscience Publishers, New York, 1963, pp. 728-741.

[26] W. A. Deer, R. A. Howie and J. Zussman, "Rock-Forming Minerals," John Wiley and Sons, New York, 1962, pp. 1-270.

[27] G. Millot, "Geologic des Argles," Mason and Cie, Paris, 1964.

[28] C. E. Weaver, "Geologic Interpretation of Argillaceous Sediments, Pt.1, Origin and Significance of Clay Minerals in Sedimentary Rocks," Bulletin of American Association of Petroleum Geology, Vol. 42, No. 2, 1958, pp. 254-271. 
[29] I. Barshad, "The Effect of a Variation in Precipitation on the Nature of Clay Minerals Formation in Soils from Acid and Basic Igneous Rocks," In: L. Heller and A. Weiss, Eds., Proceedings of International Clay Conference, Israel Programme of Scientific Translation, Jerusalem, 1966, pp. 167-173.

[30] I. Barshad and F. M. Kishk, "Chemical Composition of Soil Vermiculite Clays as Related to Their Genesis," Contribution Mineral Petroleum, Vol. 24, No. 2, 1969, pp. 136-155. doi:10.1007/BF00376887

[31] M. Singh, "Heavy Mineral Assemblage of the Pinjor Formation of the Northwestern Himalaya and Its Significance in Deciphering the Provenance of the Sediments," Geosciences, Vol. 2, No. 6, 2012, pp. 157-163, doi:10.5923/j.geo.20120206.02

[32] R. M. Garrels and C. L. Christ, "Solutions, Minerals, and Equilibria," Freeman, Cooper and Company, San Francisco, 1965.

[33] A. R. Chaudhri, "Tectonic Morphometric Studies as a Tool for Terrain Characterization in Himalayan Foothill Region-A Case Study," Journal of Geological Society of India, Vol. 79, No. 2, 2012, pp. 210-218. doi:10.1007/s12594-012-0025-Z

[34] H. Sakai, W. Yahagi, R. Fujii, T. Hayashi and B. N. Upreti, "Pleistocene Rapid Uplift of the Himalayan Frontal Ranges Recorded in the Kathmandu and Siwalik Basins," Palaeogeography, Palaeoclimatology, Palaeoecology, Vol. 241, No. 1, 2006, pp. 16-27. doi:10.1016/i.palaeo.2006.06.017

[35] M. E. Raymo, W. F. Ruddiman and P. N. Froelich, "Influence of Late Cenozoic Mountain Building on Ocean Geochemical Cycles," Geology, Vol. 16, No. 7, 1988, pp. 649-653.

doi:10.1130/0091-7613(1988)016<0649:IOLCMB $>2.3 . \mathrm{C}$ $\underline{\mathrm{O} ; 2}$

[36] W. F. Ruddiman, "Tectonic Uplift and Climate Change," Plenum Press, New York, 1997.

[37] D. Kroon, T. Steens and S. R. Troelstra, "Onset of Monsoonal Related Upwelling in the Western Arabian Sea as Revealed by Planktonice Foraminifers," Process Ocean Drilling Program Sciences Results, Vol. 117, 1991, pp. 257-263.

[38] D. K. Rea, "Delivery of Himalayan Sediment to the Northern Indian Ocean and Its Relation to Global Climate, Sea Level, Uplift and Seawater Strontium," In: R. A. Duncan, D. K. Rea, R. B. Kidd, U. von Rad and J. K. Weise, Eds., Synthesis of results from Scientific Drilling, AGU, Washington, 1992, pp. 387-402. doi:10.1029/GM070p0387

[39] K. Amano and A. Tyra, "Two-Phase Uplift of Higher Himalayas since 17 Ma," Geology, Vol. 20, No. 5, 1992, pp. 391-394. doi:10.1130/0091-7613(1992)020<0391:TPUOHH $>2.3$.C $\underline{\mathrm{O} ; 2}$

[40] L. A. Derry and C. F. Lanord, "Himalayan Weathering and Erosion Fluxes; Climate and Tectonic Controls," In: W. F. Ruddiman, Ed., Tectonic Uplift and Climate Change, Plenum, New York, 1997, pp. 290-312. doi:10.1007/978-1-4615-5935-1_12
[41] P. D. Clift, L. Giosan, J. Blusztajn, I. H. Campbell, C. Allen, M. Pringle, A. R. Tabrez, M. Danish, M. M. Rabbani, A. Alizai, A. Carter and A. Luckge, "Holocene Erosion of Lesser Himalaya Triggered by Intensified Summer Monsoon," Bulletin of Geological Society of America, Vol. 36, No. 1, 2008, pp. 79-82.

[42] K. V. Hodges, C. Wobus, K. Ruhl, T. Schildgen and K. Whipple, "Quaternary Deformation, River Steepening, and Heavy Precipitation at the Front of the Higher Himalayan Ranges," Earth and Planetary Science Letters, Vol. 220, No. 3-4, 2004, pp. 379-389, doi:10.1016/S0012-821X(04)00063-9

[43] C. Wobus, A. Heimsath, K. Whipple and K. Hodges, "Active Out-Of-Sequence Thrust Faulting in the Central Nepalese Himalaya," Nature, Vol. 434, No. 7036, 2005, pp. 1008-1011.

[44] D. W. Burbank, A. E. Blythe, J. Putkonen, B. Pratt-Sitaula, E. Gabet, M. Oskins, A. Barros and T. P. Ojha, "Decoupling of Erosion and Precipitation in the Himalayas," Nature, Vol. 426, No. 6967, 2003, pp. 652-655.

[45] D. W. Burbank and G. D. Johnson, "The Late Cenozoic Chronology and Stratigraphic Development of the Kashmir Intermontane Basin, Northwestern Himalaya," Palaeogeography, Palaeoclimatology, Palaeoecology, Vol. 43, No. 3-4, 1983, pp. 205-235. doi:10.1016/0031-0182(83)90012-3

[46] R. S. Chaudhri, "Petrogenesis of Cenozoic Sediments of Northwestern Himalayas," Geological Magazine, Vol. 108 , No. 1, 1971, pp. 43-48. doi:10.1017/S0016756800050949

[47] R. S. Chaudhri, "Heavy Mineral Distribution in the PreCenozoic Sedimentary and Metasedimentary Formations of Solon-Kandaghat-Chail Region, Himachal Himalaya," Symposium Sediment, Sedimentation and Sedimentary Environment, 1975, pp. 48-57.

[48] M. L. Jackson, "Frequency Distribution of Clay Minerals in Major Soil Groups as Related to Factors of Soil Formation," Clays and Clay Minerals, Vol. 6, 1959, pp. 133143. doi:10.1346/CCMN.1957.0060111

[49] P. M. Hurley, D. G. Brookins, W. H. Pinson, S. R. Hearth and H. W. Fairbairn, "K-Ar Age Studies of Mississippi and Other River Sediments," Geological Society of America Bulletin, Vol. 72, No. 12, 1961, pp. 1807-1816. doi:10.1130/0016-7606(1961)72[1807:KASOMA]2.0.CO ;2

[50] H. D. Foth and L. M. Truck, "Fundamentals of Soil Science," Wiley Eastern Pvt. Ltd., New Delhi, 1973, pp. $1-454$.

[51] H. Milne and J. W. Earley, "Effect of Source and Environment on Clay Minerals," Bulletin of American Association of Petroleum Geology, Vol. 42, No. 2, 1958, pp. 328-338.

[52] H. F. Shaw, "Clay Minerals in Sediments and Sedimentary Rocks," In: G. D. Hobson, Ed., Developments in Petroleum Geology, Allied Sciences Publication Ltd., London, 1980, pp. 53-85.

[53] B. Velde, "Diagenetic Reactions in Clays," In: A. Parker and B. W. Sellwood, Eds., Sediment Diagenesis, D. Reidel Publication Company, Dordrecht, 1983, pp. 215-268. 
doi:10.1007/978-94-009-7259-9_4

[54] R. S. Chaudhri and C. K. Kalita, "X-Ray Study of Clay Minerals of the Krol Formation of the Mussoorie Hills, Kumaon Himalaya," Indian Journal of Earth Sciences, Vol. 12, No. 4, 1985, pp. 239-248.

[55] M. Singh, "Sedimentology of the Pinjor Formation Exposed in the Type Area Pinjore and Surrounding Regions," Ph.D. Thesis, Kurukshetra University, Kurukshetra, 2009.

[56] S. Clemens, W. Prell, D. Murray, G. Shimmield and G. Weedon, "Forcing Mechanisms of the Indian Ocean Monsoon," Nature, Vol. 353, No. 6346, 1991, pp. 720-725. doi: $10.1038 / 353720 \mathrm{a} 0$

[57] J. Overpeck, D. Anderson, S. Trumbore and W. Prell,
"The Southwest Indian Monsoon over the Last 18,000 Years," Climate Dynamics, Vol. 12, No. 3, 1996, pp. 213225. doi:10.1007/BF00211619

[58] H. Pang, Y. He, Z. Zhang, A. Lu and J. Gu, "The Origin of Summer Monsoon Rainfall at New Delhi by Deuterium Excess," Hydrology and Earth System Sciences, Vol. 8, No. 1, 2004, pp. 115-118. doi:10.5194/hess-8-115-2004

[59] M. T. Hren, M. Pagani, D. M. Erwin and M. Brandon, "Biomarker Reconstruction of the Early Eocene Paleotopography and Paleoclimate of the Northern Sierra Nevada," Geology, Vol. 38, No. 1, 2010, pp. 7-10. doi:10.1130/G30215.1 